Article

\title{
Similarities in Virulence and Extended Spectrum Beta-Lactamase Gene Profiles among Cefotaxime-Resistant Escherichia coli Wastewater and Clinical Isolates
}

\author{
Elizabeth Liedhegner ${ }^{1}$, Brandon Bojar ${ }^{1}$, Rachelle E. Beattie ${ }^{2} \mathbb{D}$, Caitlin Cahak ${ }^{3}$, Krassimira R. Hristova ${ }^{2}$ \\ and Troy Skwor ${ }^{1, *(D)}$
}

1 Department of Biomedical Sciences, College of Health Sciences, University of Wisconsin-Milwaukee, Milwaukee, WI 53211, USA; liedhegn@uwm.edu (E.L.); bbojar@uwm.edu (B.B.)

2 Department of Biological Sciences, Marquette University, Milwaukee, WI 53233, USA; rachelle.beattie20@gmail.com (R.E.B.); krassimira.hristova@marquette.edu (K.R.H.)

3 Wisconsin Diagnostic Laboratories, Milwaukee, WI 53226, USA; ccahak@wisconsindiagnostic.com

* Correspondence: skwor@uwm.edu

check for

updates

Citation: Liedhegner, E.; Bojar, B.; Beattie, R.E.; Cahak, C.; Hristova, K.R.; Skwor, T. Similarities in Virulence and Extended Spectrum Beta-Lactamase Gene Profiles among Cefotaxime-Resistant Escherichia coli Wastewater and Clinical Isolates. Antibiotics 2022, 11, 260. https:// doi.org/10.3390/antibiotics11020260

Academic Editor: Lucia Bírošová

Received: 26 January 2022

Accepted: 15 February 2022

Published: 17 February 2022

Publisher's Note: MDPI stays neutral with regard to jurisdictional claims in published maps and institutional affiliations.

Copyright: (c) 2022 by the authors. Licensee MDPI, Basel, Switzerland. This article is an open access article distributed under the terms and conditions of the Creative Commons Attribution (CC BY) license (https:// creativecommons.org/licenses/by/ $4.0 /)$.

\begin{abstract}
The World Health Organization has identified antibiotic resistance as one of the largest threats to human health and food security. In this study, we compared antibiotic resistance patterns between ESBL-producing Escherichia coli from human clinical diseases and cefotaxime-resistant environmental strains, as well as their potential to be pathogenic. Antibiotic susceptibility was tested amongst clinical isolates $(n=11)$, hospital wastewater $(n=22)$, and urban wastewater $(n=36$, both influent and treated effluents). Multi-drug resistance predominated $(>70 \%)$ among hospitalwastewater and urban wastewater influent isolates. Interestingly, isolates from clinical and urban treated effluents showed similar multi-drug resistance rates ( $50 \%)$. Most hospital wastewater isolates were Phy$\operatorname{logroup} \mathrm{A}$, while clinical isolates were predominately B2, with a more diverse phylogroup population in urban wastewater. ESBL characterization of cefotaxime-resistant populations identified bla $_{\mathrm{CTX}-\mathrm{M}-1}$ subgroup as the most common, whereby $b l a_{\mathrm{KPC}}$ was more associated with ceftazidime and ertapenem resistance. Whole-genome sequencing of a carbapenemase-producing hospital wastewater $E$. coli strain revealed plasmid-mediated $b a_{\mathrm{KPC}-2}$. Among cefotaxime-resistant populations, over $60 \%$ of clinical and $30 \%$ of treated effluent $E$. coli encoded three or more virulence genes exhibiting a pathogenic potential. Together, the similarity among treated effluent E. coli populations and clinical strains suggest effluents could serve as a reservoir for future multi-drug resistant $E$. coli clinical infections.
\end{abstract}

Keywords: wastewater; ESBL; KPC; CTX-M; virulence; uropathogenic

\section{Introduction}

Antimicrobial resistance (AMR) is a serious global health concern. In the United States alone, over 2 million AMR infections are reported annually, resulting in approximately 23,000 deaths [1]. Although AMR is frequently associated with the overuse and misuse of antibiotics in clinical settings, resistant bacteria and their genes are widespread within human, animal, and environmental settings, indicating the need for a One Health approach [2]. Wastewaters are ideal for the study of AMR as they serve as a bridge between human, animal, and environmental settings and have been frequently implicated in the acquisition and dissemination of AMR bacteria and genes [3,4]. Additionally, wastewaters are rich in selective pressures including antibiotics, pharmaceuticals, and biocides that can increase microbial horizontal gene transfer (HGT) and mutation rates, leading to an increase in AMR [5,6].

Wastewaters contain bacteria from a variety of sources including human waste, stormwater, and hospital sewage. Due to the widespread use of broad-spectrum antibiotics for disease treatment in hospital settings, hospital wastewater frequently contains 
elevated levels of antibiotic residues and antibiotic resistant bacteria, many of which are resistant or resilient to wastewater (WW) treatment processes $[7,8]$ and enter urban waterways and recreational waters $[9,10]$. Bacterial populations that survive the WW treatment process, whether pathogenic or not, serve as a health risk in downstream receiving waters by increasing the dissemination of AMR bacteria and their genes.

Specific classes of hospital-administered antibiotics pose greater human health risk if disseminated into the environment. One such last-resort antibiotic class, third-generation cephalosporins, is frequently used as a front-line therapeutic against serious Gram-negative bacterial infections [1]. Increased activity beta-lactams comprise $10.6 \%$ of all prescribed antibiotics in the United States [11]. However, The United States Center for Disease Control and Prevention (CDC) has identified strains of the family Enterobacterales resistant to this class of antibiotics as a major public health threat [1]. Resistance to cephalosporins is mediated by a diverse group of antibiotic resistance genes (ARGs) called extended spectrum beta-lactamase (ESBLs) [12]. ESBL-producing E. coli populations are defined by resistance to penicillins, cephalosporins, and aztreonam that can be inhibited by betalactamase inhibitors like clavulanic acid [13]. These ESBLs are highly associated with mobile genetic elements capable of being passed to other bacteria via horizontal gene transfer (HGT) [14], which can be elevated by many stressors present in the WW [15]. A better understanding of the contribution of hospital WW to the presence and dissemination of ESBLs throughout the WW treatment system is necessary to determine human health risk in downstream receiving waters, as well as further assessing the potential of resistant populations to be pathogenic.

Escherichia coli populations comprise both pathogenic and commensal strains and are strong indicator species of warm-blooded animal and human fecal waste [16]. AMR populations of E. coli present two public health threats: increased difficulty to treat clinically and ability to transfer ARGs both intra- and interspecies [17], thus being a vehicle of ARG dissemination. Identifying similarities in AMR phenotypes and genotypes, as well as virulence factors between isolates from interconnected ecosystems, can help identify areas in which gene transfer may be occurring that are in critical need of AMR mitigation and control measures. In areas that release treated wastewater into local receiving waters accessed by humans and animals, this evaluation is vital to reduce potential health risks. Previous studies by our labs have characterized antibiotic resistance phenotypes and genotypes of E. coli from manure, wastewater, sediment and surface waters, hospital wastewater, and clinical strains $[10,18,19]$. This study expands on our previous findings through the following aims: (i) to assess the presence of cefotaxime (CTX)-resistant Escherichia coli populations in hospital and urban WW; (ii) to compare resistance patterns among clinical ESBL-producing E. coli to urban and hospital WW strains within a defined geographical location; and (iii) to further assess the presence of virulence factors among cefotaxime resistant populations to provide a more complete public health risk analysis.

\section{Results and Discussion}

\subsection{Characterization of Antibiotic Resistance Profiles of Cefotaxime-Resistant E. coli}

Among the leading antimicrobial resistance threats facing healthcare, ESBL-producing Enterobacterales pose a serious health threat with higher healthcare costs and longer hospital stays [20]. Furthermore, the worldwide carriage rate of ESBL-producing E. coli populations has significantly increased over eight-fold (2.6\% to $21.1 \%)$ in less than 15 years [21]. Combating this issue involves utilizing a One Health approach, recognizing that AMR is interconnected between the clinic, agriculture, and the environment. In this study, we examined ESBL-producing E. coli isolates from a variety of clinical sources (7- uropathogenic E. coli (UPEC), 2- bacteremia, 1- wound infection, and 1- surgical tissue infections) from Milwaukee, Wisconsin, U.S.A. All selected isolates exhibited at least intermediate resistance to third-generation cephalosporins or carbapenems. Clinical isolates were analyzed for their antibiotic resistance profiles and were compared to cefotaxime-resistant $E$. coli isolates from WW effluents of the same hospital $(n=22)$, as well as influents $(n=19)$ 
and treated effluents $(n=17)$ from urban wastewater reclamation facility in the same city. The Milwaukee wastewater reclamation facility services 1.1 million people within a 681 $\mathrm{km}^{2}$ area collecting and treating on average $265 \mathrm{~mL} /$ day of sewage during dry days. The sewage comprises domestic urban surface runoff, industrial, and hospital wastewater. The final treated wastewater is discharged into Lake Michigan within the Milwaukee Bay area (43.02329162715021, -87.89408612678749). Similar to a global analysis of disinfected WW effluents [22], no CTX-resistant E. coli isolates were identified in post-chlorinated WW effluents. The $69 \mathrm{E}$. coli isolates were tested for resistance against twelve different antibiotics. Hospital WW displayed the same or highest prevalence of antibiotic resistance compared to all other E. coli sources except for chloramphenicol (CHL), to which all isolates were fully susceptible (Figure 1). Although antibiotic resistance was not as prevalent among WW influents and effluents, more than $25 \%$ of isolates were resistant to five antibiotics (sulfamethoxazole-trimethoprim (SXT), tetracycline (TET), ceftriaxone (CRO), ceftazidime (CAZ), and CTX) (Supplementary Table S2).

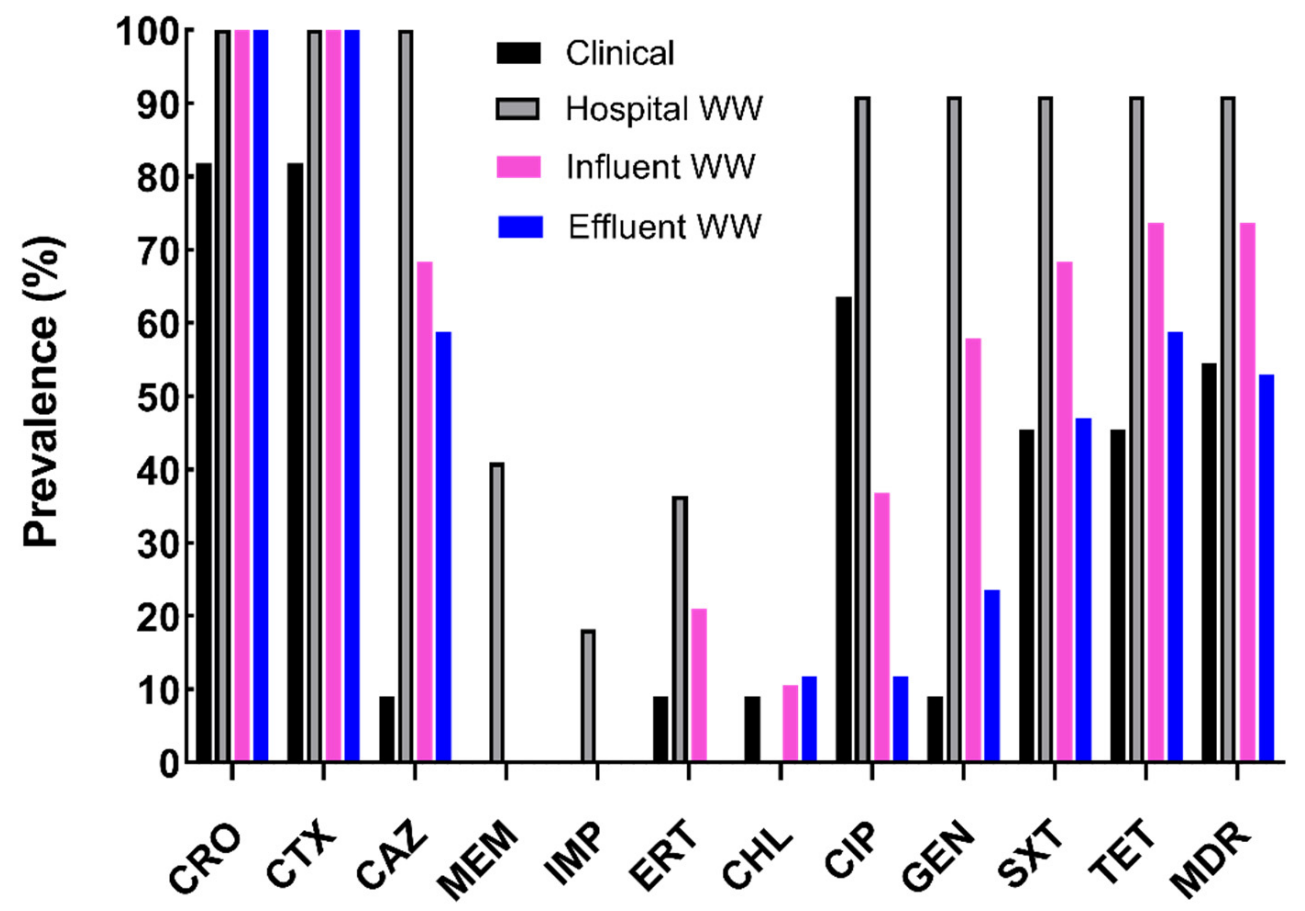

Figure 1. Prevalence of antibiotic resistance among Escherichia coli isolates. CTX-resistant clinical ( $n=11$, black) and wastewater (WW) isolates were analyzed for antibiotic susceptibility using disk diffusion. Isolates from wastewater populations included hospital ( $n=22$, gray), wastewater influent ( $n=19$, pink), and treated effluent $(n=17$, blue). Prevalence was determined dividing resistant isolates by the total number of isolates in each source multiplied by a hundred. CRO: ceftriaxone; CTX: cefotaxime; CAZ: ceftazidime; MEM: meropenem; IMP: impenem; ERT: ertapenem; CHL: chloramphenicol; CIP: ciprofloxacin; GEN: gentamicin; SXT: sulfamethoxazole-trimethoprim; TET: tetracycline; MDR: multi-drug resistant.

Multi-drug resistance ( $\geq 3$ antibiotic classes), a major health threat, was evident among over $71 \%$ (49 or 69 ) of isolates with the highest prevalence among hospital WW and urban influent WW (Figure 1: 91\% and 74\% respectively). Most CTX-resistant hospital WW E. coli were also resistant to SXT, gentamicin (GEN), and ciprofloxacin (CIP) (Supplementary Table S2), consistent with another report [23]. Resistance to these three antibiotics (SXT, GEN, and CIP), albeit at lower levels, was persistent throughout influent $(68 \%, 58 \%$, and $39 \%$, respectively) and effluent (47\%, 24\%, and $12 \%$, respectively). Although antibiotic resistant profiles were quite diverse within and among the sample sources (Supplementary Table S2), resistance to SXT, GEN, CIP, TET, CRO, CAZ, and CTX 
were the most prevalent among hospital and urban influent WW. Similar to other reports [24], hospital WW isolates had significantly higher multiple antibiotic resistance (MAR) indices than all other sources (Figure 2A: $p<0.05$ ).
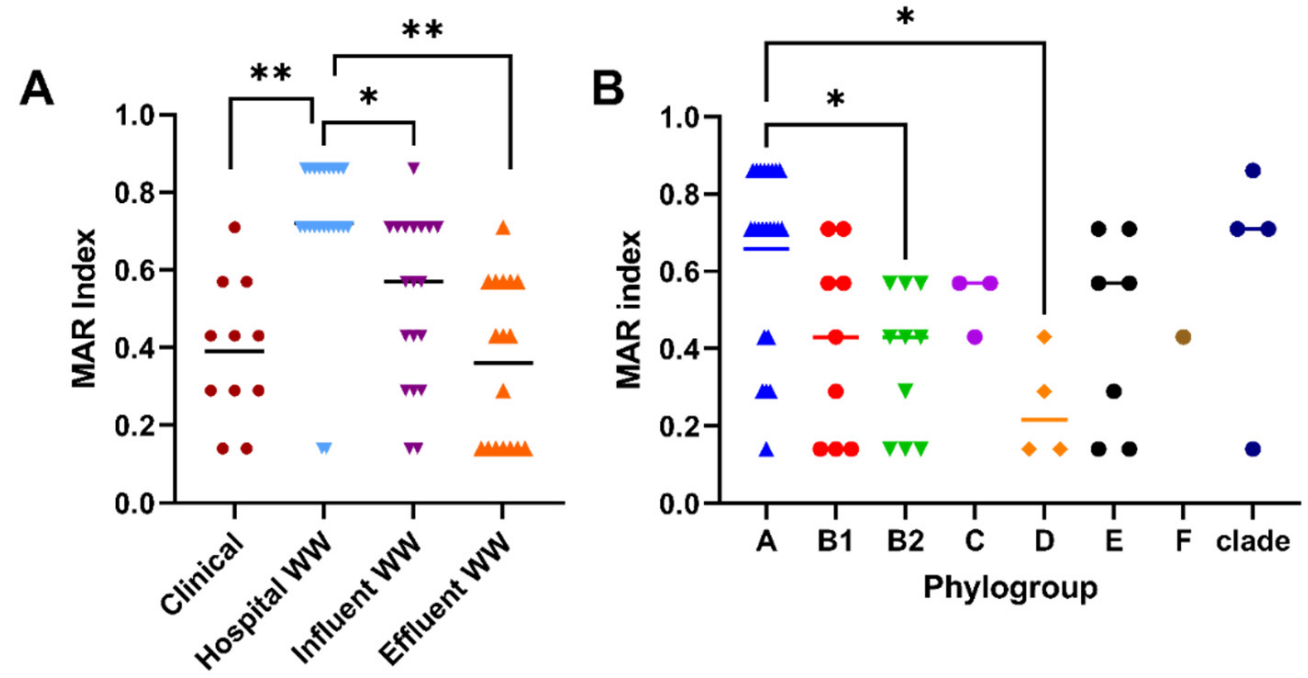

Figure 2. Antibiotic resistance among sample sources and phylogroups. (A) Multiple antibiotic resistance (MAR) index was determined by dividing the number of resistant antibiotic categories by the total number of antibiotic categories $(n=7)$ per isolate. (B) Phylogroup of total isolates was determined using the revised Clermont method. Each mark represents one isolate. The mean of each group is represented by a bar. Statistical differences between sources or phylogroups was determined using Tukey's multiple comparison test. ${ }^{*} p<0.05 ;{ }^{* *} p<0.001$.

In addition to antibiotic susceptibility, we also categorized these E. coli by phylogroup [25], which aids in identifying a possible common bacterial host or origin. Most clinical isolates (64\%) were attributed to phylogroup B2 (Supplementary Table S3), which correlated with the abundance of uropathogenic strains [26] amongst our clinical population. Interestingly, B2 was also present in WW influents (7\%) and treated effluent (13\%) isolates, though not observed in hospital WW (Supplementary Table S3). The majority of hospital WW was comprised of phylogroup A (77\%), which typically associates as human commensal origin [27]. In agreement with other studies [19,28], WW influents and effluents showed a greater diversity in phylogroups (Supplementary Table S3) likely due to multiple sources combining into one, as well as WW persistent populations [27]. Amongst all the phylogroups, isolates typed to phylogroup A were significantly more resistant than those typed to $\mathrm{B} 2$ and $\mathrm{D}$ (Figure $2 \mathrm{~B}, p<0.05$ ). This finding could be attributed to microbial source, as phylogroup A comprised most samples from hospital WW, similar to other reports $[19,29,30]$.

\subsection{Prevalence of $\beta$-Lactamases among CTX-Resistant Populations}

Among CTX-resistant E. coli populations from the clinic and environmental sources, we assessed the presence of seven different $\beta$-lactamases: CTX-M subgroups $(1,2$, and 9), TEM, SHV, OXA, and KPC. They have become a global pandemic with ESBL prevalence increasing among commensals and clinical isolates [21,31], causing significant therapeutic challenges [32]. Women with ESBL-producing E. coli urinary tract infections are significantly more likely to contain the same ESBL-producing E. coli clone in their feces [33]. From a One Health perspective, the strongest correlation of ESBL genes among commensal and pathogenic isolates is with environmental sources, specifically surface and WW [34], in contrast to agricultural sources. One of the most common ESBLs that continues to increase in prevalence is the CTX-M family [34,35]. CTX-M enzymes originally targeted cefotaxime; however, their predominant presence in mobile genetic elements increased the variability and hydrolytic activity to other cephalosporins, including ceftazidime [36]. Furthermore, 
intra- and interspecies HGT within WW poses an additional threat with the evolution of chimeric CTX-M genes [37]. In our study, CTX-M-1 subgroup was the most common among ESBLs (Table 1: $81 \%$ of total samples analyzed) where $95 \%$ of cefotaxime-resistant hospital WW populations encoded $b l a_{\text {СтХ-M-1 }}$ subgroup followed by $73 \%$ of urban WW influent and $81 \%$ of treated effluent isolates (Table 1). Resistance to CRO and CTX were significantly correlated with strains encoding $b l a_{\mathrm{CTX}-\mathrm{M}-1}$ (Figure $3, p=0.0001$ ). Among clinical isolates, the CTX-M-1 subgroup predominated as the second most common ESBL among clinical strains, where it was encoded by $64 \%$ of isolates (Table 1 ). The CTX-M-1 subgroup is the most common ESBL within hospital isolates from North America comprising between $34 \%$ and $66.2 \%$ [38,39]. Another study demonstrated $79 \%$ and $67 \%$ of ESBL-producing E. coli phylogroup B2 strains from urine and feces, respectively, encoded CTX-M-1 subgroup compared to $21 \%$ and $25 \%$ CTX-M-9 subgroup [33].

Table 1. Prevalence of $\beta$-lactamases and int1 genes among E. coli populations.

\begin{tabular}{|c|c|c|c|c|c|c|c|c|c|}
\hline \multirow[b]{2}{*}{ Source } & \multirow[b]{2}{*}{$\mathbf{N}$} & \multicolumn{8}{|c|}{ Prevalence (\%) } \\
\hline & & $\begin{array}{l}\text { CTX-M-1 } \\
\text { Subgroup }\end{array}$ & $\begin{array}{l}\text { CTX-M-2 } \\
\text { Subgroup }\end{array}$ & $\begin{array}{c}\text { CTX-M-9 } \\
\text { Subgroup }^{\text {a }}\end{array}$ & TEM & OXA & SHV & $\mathrm{KPC}^{\mathrm{b}}$ & int1 \\
\hline Clinical & 11 & $7(64)$ & 0 & $1(9)$ & $11(100)$ & $5(45)$ & 0 & 0 & $7(64)$ \\
\hline Hospital WW & 22 & $21(95)$ & 0 & 0 & $13(59)$ & $19(86)$ & 0 & $9(41)$ & $17(77)$ \\
\hline Urban Influent & 15 & $11(73)$ & 0 & $4(27)$ & $11(73)$ & $10(67)$ & 0 & 0 & $8(53)$ \\
\hline Treated effluent & 16 & $13(81)$ & 0 & $5(31)$ & $12(75)$ & $13(81)$ & 0 & 0 & $9(56)$ \\
\hline Total & 64 & $52(81)$ & 0 & $10(16)$ & 47 (73) & $47(73)$ & 0 & $9(14)$ & $41(64)$ \\
\hline
\end{tabular}

a Statical difference between sources $p=0.005 ;{ }^{\mathrm{b}} p<0.001$.

The CTX-M-9 subgroup was more prevalent among urban WW isolates compared to clinical and hospital WW (Table 1, $p=0.005$ ). Although not as common as CTX-M-1 subgroup, the CTX-M-9 subgroup members were initially found on conjugative plasmids [40]. This subgroup, along with CTX-M-1, is commonly present within hospital sinks [41]. Others have found both CTX-M subgroups 1 and 9 at similar frequencies among WW influent E. coli populations [37]. Within the United States, CTX-M subgroups 1 and 2 have been located without subgroup 9, based on total WW DNA analysis [42]. Bevan et al. reviewed 220 articles about CTX-M subgroups and identified a predominate geographic distribution of CTX-M-1 and -9 subgroups among most of the world, though some countries in South America display a stronger CTX-M-2 subgroup population [43]. Our findings agree with the worldwide CTX-M-1 and -9 subgroup pattern and no CTX-resistant isolates encoding CTX-M-2 subgroup. With the advent of sequencing technologies providing more affordable sequencing options, it is important to distinguish between the health risks associated with ESBL findings from total DNA compared to bacterial isolates.

Among the other $\beta$-lactamase genes analyzed in our study, bla $a_{\mathrm{TEM}}$ and $b l a_{\mathrm{OXA}}$ were carried by $73 \%$ of isolates (Table 1). Both ESBLs were found on a relatively high percentage in all sources, although clinical sources, like Branger et al. [44], had the highest prevalence of $b l a_{\text {TEM }}$ compared to hospital WW isolates, which had the lowest prevalence (Table 1: $100 \%$ vs. $59 \%$, respectively). However, this pattern was reversed with bla OXA, where $86 \%$ of hospital WW isolates encoded it, though only $45 \%$ of clinical strains carried the gene (Table 1). Further analysis of bla $a_{\mathrm{TEM}}$ and bla $_{\mathrm{OXA}}$ genotypes with resistance phenotypes did not identify any significant correlations (Table 2). Our study did not identify any $b l a_{\mathrm{SHV}^{-}}$ encoding CTX-resistant strains from either hospital or urban WW. This is in agreement with other studies worldwide reporting a predominance in TEM, OXA, and CTX-M [45,46]. 


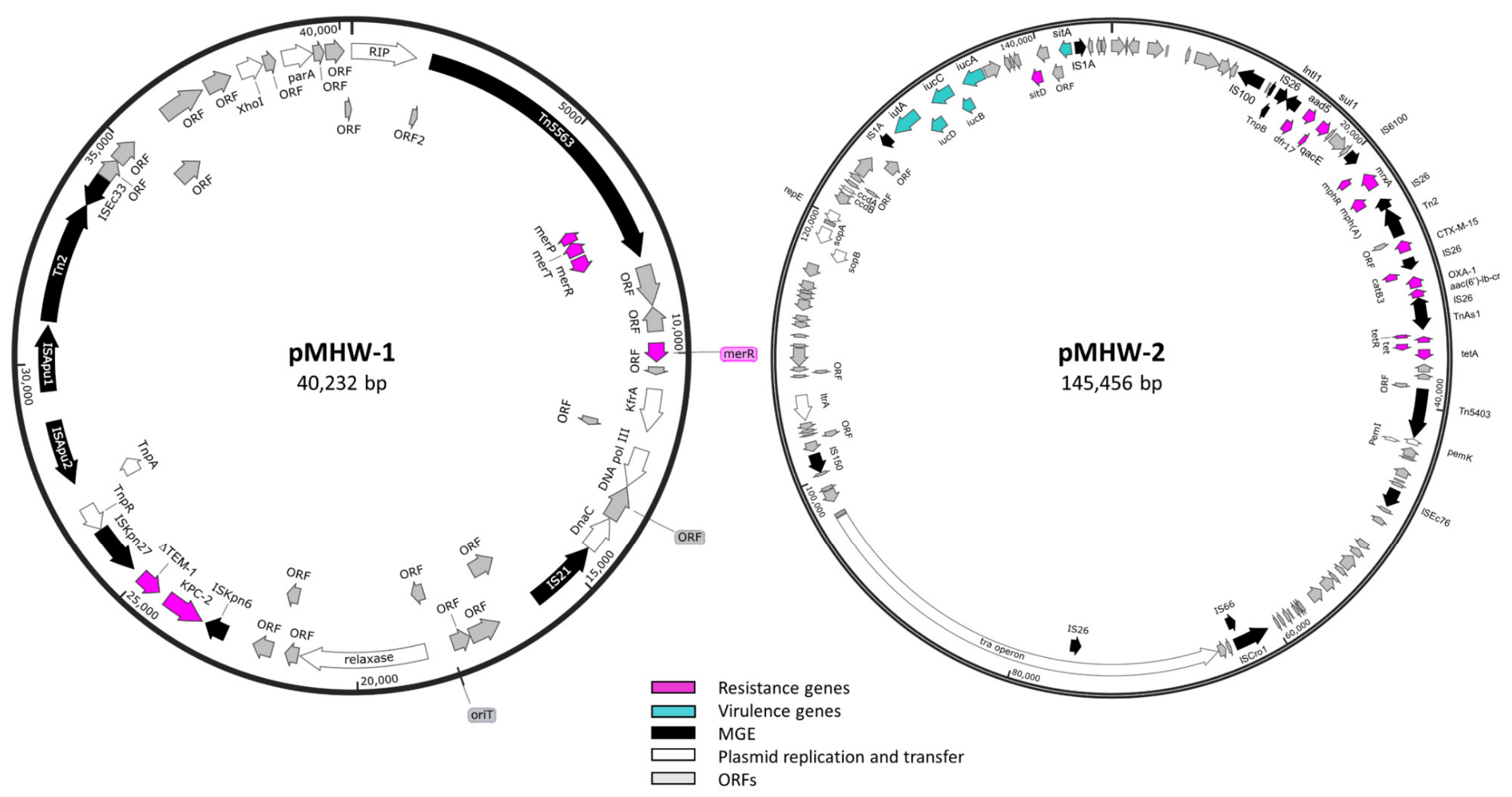

Figure 3. Plasmid maps from hospital wastewater E. coli 1000C-3 isolate. Plasmids sequences were determined from long-read Nanopore and Illumina short paired-end reads. pMHW- 1 was identified as a 40,232 bps mobilizable IncP-6-type plasmid, and pMHW-2 as a 145,456 bps conjugative IncF plasmid containing a tra operon. Arrows are color-coded exhibiting genes involved in drug resistance (fuchsia), virulence (blue), mobile genetic elements (MGE) (black), plasmid replication, maintenance and transfer (white), and opening reading frames (ORFs) (grey) 
Table 2. Correlation of antibiotic resistance phenotypes and genotypes.

\begin{tabular}{|c|c|c|c|c|c|c|c|c|c|c|}
\hline & CAZ & CRO & CTX & ERT & ESBL & $b l a_{\mathrm{CTX}-\mathrm{M}}$ & ${ }_{1} b l a_{\mathrm{CTX}-\mathrm{M}}$ & bla $a_{\mathrm{OXA}}$ & $b l a_{\mathrm{TEM}}$ & $b l a_{\mathrm{KPC}}$ \\
\hline CAZ & 1 & & & & & & & & & \\
\hline CRO & $\begin{array}{l}0.1176 \\
0.3548\end{array}$ & 1 & & & & & & & & \\
\hline CTX & $\begin{array}{l}0.1176 \\
0.3548\end{array}$ & $\begin{array}{c}1.0000 \\
0.0000\end{array}$ & 1 & & & & & & & \\
\hline ERT & $\begin{array}{c}0.2925 * \\
0.0190\end{array}$ & $\begin{array}{c}-0.0949 \\
0.4557\end{array}$ & $\begin{array}{c}-0.0949 \\
0.4557\end{array}$ & 1 & & & & & & \\
\hline ESBL & $\begin{array}{c}-0.3945 \\
0.0013\end{array}$ & $\begin{array}{l}0.2361 \\
0.0604\end{array}$ & $\begin{array}{l}0.2361 \\
0.0604\end{array}$ & $\begin{array}{c}-0.3190 \\
0.0102\end{array}$ & 1 & & & & & \\
\hline$b l a_{\mathrm{CTX}-\mathrm{M}-1}$ & $\begin{array}{l}0.1732 \\
0.1711\end{array}$ & $\begin{array}{c}0.4616^{*} \\
0.0001\end{array}$ & $0.4616^{*}$ & $\begin{array}{l}0.0066 \\
0.9585\end{array}$ & $\begin{array}{c}0.2707^{*} \\
0.0305\end{array}$ & 1 & & & & \\
\hline$b l a_{\text {CTХ-M-9 }}$ & $\begin{array}{c}-0.4326 \\
0.0004\end{array}$ & $\begin{array}{l}0.0954 \\
0.4532\end{array}$ & $\begin{array}{l}0.0954 \\
0.4532\end{array}$ & $\begin{array}{c}-0.1960 \\
0.1205\end{array}$ & $\begin{array}{l}0.0593 \\
0.6417\end{array}$ & $\begin{array}{l}-0.2343 \\
0.0624\end{array}$ & 1 & & & \\
\hline$b l a_{\mathrm{OXA}}$ & $\begin{array}{l}0.1508 \\
0.2342\end{array}$ & $\begin{array}{l}0.0340 \\
0.7897\end{array}$ & $\begin{array}{l}0.0340 \\
0.7897\end{array}$ & $\begin{array}{c}-0.0076 \\
0.9542\end{array}$ & $\begin{array}{c}-0.1396 \\
0.2713\end{array}$ & $\begin{array}{l}-0.0170 \\
0.8940\end{array}$ & $\begin{array}{l}-0.1309 \\
0.3024\end{array}$ & 1 & & \\
\hline$b l a_{\mathrm{TEM}}$ & $\begin{array}{c}-0.2093 \\
0.0969\end{array}$ & $\begin{array}{l}0.0340 \\
0.7897\end{array}$ & $\begin{array}{l}0.0340 \\
0.7897\end{array}$ & $\begin{array}{c}-0.2886 \\
0.0207\end{array}$ & $\begin{array}{l}0.1440 \\
0.2563\end{array}$ & $\begin{array}{l}0.0736 \\
0.5630\end{array}$ & $\begin{array}{l}0.1614 \\
0.2027\end{array}$ & $\begin{array}{l}-0.2015 \\
0.1103\end{array}$ & 1 & \\
\hline$b l a_{\mathrm{KPC}}$ & $\begin{array}{c}0.3346^{*} \\
0.0069\end{array}$ & $\begin{array}{l}0.0897 \\
0.4808\end{array}$ & $\begin{array}{l}0.0897 \\
0.4808\end{array}$ & $\begin{array}{c}0.6497^{*} \\
0.0000\end{array}$ & $\begin{array}{c}-0.2505 \text { * } \\
0.0459\end{array}$ & $\begin{array}{l}0.1943 \\
0.1239\end{array}$ & $\begin{array}{c}-0.1741 \\
0.1689\end{array}$ & $\begin{array}{l}0.1415 \\
0.2647\end{array}$ & $\begin{array}{c}-0.3673 \\
0.0028\end{array}$ & 1 \\
\hline
\end{tabular}

Data from antibiotic susceptibility patterns against third-generation cephalosporins and carbapenems, as well as beta-lactamases, from all isolates were analyzed using Pearson's correlation coefficients. The top value represents the correlation coefficient while the bottom number indicates the $p$-value. Values with statistically significant differences are in bold with an asterisk (*). ESBL: extended spectrum beta-lactamase.

When assessing the risk of ARGs within environmental bacterial populations, it is important to assess if the ARGs encoding resistance against currently used antibiotics, especially last-resort antibiotics, are found on mobile genetic elements [47]. In our study, we have identified plasmid-mediated resistance to third-generation cephalosporins (Supplementary Table S4) from WW sources. Additionally, class 1 integron-integrase gene (int1) was found among $65 \%$ of all CTX-resistant populations with similar levels amongst clinical and WW populations (Table 1: $64.4 \%$ and $64.2 \%$ respectively). Our findings agree with others who identify int 1 commonly throughout WW treatment process [48], as well as harboring gene cassettes encoding ARGs [19], thus supporting its use as an indicator of arthropogenic pollution [49]. Widespread dissemination of int1 among diverse bacterial populations within mobile genetic elements, such as plasmids and transposons, supports a strong association of their presence with the rapid evolution of antibiotic resistance [49].

With carbapenems traditionally used to treat ESBL-producing Enterobacteriaceae infections, the evolution of carbapenemases pose a direct threat to therapeutic options. Enterobacteriaceae-produced carbapenemases are primarily grouped into Ambler class A (Klebsiella pneumoniae carbapenemase (KPC) and GES), class B (metallo- $\beta$-lactamases (MBL) like NDM, VIM, and IMP), or class D (OXA-48-like enzymes) [50]. Of these, KPC-producers are the most endemic throughout the Americas, parts of Europe, and China, while spreading globally [51]. Amongst our cefotaxime-resistant E. coli populations, hospital WW was the only source that carried bla $a_{\mathrm{KPC}}$ (Table 1: 41\%, $p<0.001$ ). The presence of $b l a_{\mathrm{KPC}}$ was significantly correlated with carbapenem and ceftazidime resistance and the absence of bla TEM (Table $2, p<0.01$ ). Other research has found that the highest prevalence of clinical bla $a_{\mathrm{KPC}}$ appears within inpatient facilities, peaking in long-term acute care hospitals [51].

\subsection{Whole-Genome Sequence Analysis of Carbapenemase-Producing E. coli Isolate}

To further characterize the $b l a_{\mathrm{KPC}}$-encoding populations, we sequenced one of the hospital WW isolates, E. coli 1000C-3 (Accession number CP091427), using long- and short-read sequencing. The genome contained 4,839,424 nucleotides with $50.75 \%$ GC content, 4,944 putative ORFs, and was identified as O101:H9 serotype, which has previously been associated with pathogenic and commensal strains [52]. It has also been found among calves with gastroenteritis [53]. Whole-genome sequencing identified this strain as sequence type (ST) 167 , which has previously been associated with $b l a_{K P C}$ encoding 
strains, and Inc types [54]. ST167 has been emerging globally, suggesting it as a high-risk clone [55]. In our study, 1000C-3 was resistant to SXT, GEN, CIP, TET, CTX, CRO, CAZ, meropenem (MEM), imipenem (IPM), and ertapenem (ERT) (Supplementary Table S2). The following resistance phenotypes were predicted using ResFinder based on the vast array of ARGs: aminocyclitol, macrolides, quaternary ammonium compounds, fluoroquinolones, phenicols, peroxides, aminoglycosides, tetracyclines, cephalosporins, and carbapenems. The chromosome encoded numerous ARGs involved in resistance to tetracycline (e.g., tet $B$ ), macrolides (e.g., $m d f(A))$, beta-lactams (e.g., ampC), and aminoglycosides (e.g., $k d p E$ ), as well an array of multidrug major facilitator superfamily (MFS) (Table 3: emrAB, emrKY) and resistance-nodulation-cell division (RND) efflux pumps (Table 3: AcrAB-TolC; AcrAD-TolC, MdtEF). These efflux pumps not only serve to export drugs and toxins but also aid in host colonization and dissemination through biofilm formation [56] and evasion of innate host defenses [57]. Additionally, E. coli 1000C-3 strain contained point mutations in parC, parE, and $g y r A$, providing quinolone resistance (Table 3).

Beyond the resistance genotypes encoded chromosomally, E. coli 1000C-3 carried a mobilizable (pMHW-1: Accession number CP091429) and conjugative (pMHW-2) R plasmid. The smaller mobilizable plasmid, pMHW-1, was identified as an IncP-6 plasmid (Supplementary Table S5: 100\% coverage and 99.88\% identity to IncP-6 from Serratia marcescens accession number JF785550) with 40,232 base pairs and $57.87 \%$ GC content with 49 predicted ORFs, including carbapenemase bla $a_{\mathrm{KPC}-2}$ (Figure 3 and Supplementary Table S6). The IncP-6 (assign to IncG in E. coli) replicon and $b l a_{\mathrm{KPC}-2}$ have been identified amongst a variety of genera, including Aeromonas spp., Klebsiella spp., Pseudomonas spp., and E. coli acquired from environmental, animal waste, and clinical sources [54]. pMHW-1 shared over 99.8\% identity with other plasmids sequences from Pseudomonas aeruginosa, Citrobacter braakii and C. freundii, Klebsiella pneumoniae, Aeromonas veronii and A. hydrophila, and E. coli, although only up to $89 \%$ coverage (Supplementary Table S7). The bla $a_{\mathrm{KPC}-2}$ was just upstream of a truncated bla netic arrangement: ISKpn6-bla $a_{\mathrm{KPC}-2}-b l a_{\mathrm{TEM}-1}-\mathrm{ISK} p n 27$ has been evident in IncP6 from a variety of clinical and WW species [58]. pMHW-1 also carried transposon Tn5563, a member of the Tn3 transposon family, with a mercury operon encoding the periplasmic scavenger mer $P$, transporter merT, and regulator merR (Figure 3). However, this strain lacks the detoxifying mercuric reductase mer $A$, resulting in increased uptake of environmental mercury creating a hypersensitive strain [59]. Plasmid pMHW-1 appeared to be a mobilizable plasmid with an identifiable oriT site and relaxase gene (Figure 3 and Supplementary Table S6). It also encodes a replication initiation protein (RIP), as well as some genes aiding its replication and maintenance: parA, DNA polymerase III, $k f r A$, and dnaC (Supplementary Table S6).

We also identified pMHW-2 (Accession number: CP091428), a multi-drug resistant self-transmissible IncFIA plasmid in E. coli 1000C-3 (Supplementary Table S5: 99.74\% coverage and $99.48 \%$ identity with E. coli plasmid F Accession number AP001918) consisting of 145,445 bps with 52\% GC content and 196 predicted ORFs. IncF plasmids are commonly associated with multi-drug resistant E. coli strains from the clinic, animals, and the environment [60]. This plasmid shared homology with numerous plasmids from E. coli (Supplementary Table S7). Conjugative pMHW-2 plasmid contained a tra operon with 30 genes aiding self-transmissibility (Figure 3 and Supplementary Table S6). These genes are involved in the regulation of transcription, relaxosome formation, type 4 secretion system, pilus formation, and mating pair formation [61]. pMHW-2 plasmid also contains a Tn5403, Tn3-like transposon, which has been identified to contain enzymes capable of helping non-conjugative plasmids [62]. 
Table 3. Resistome of MDR hospital wastewater E. Coli 1000C-3 isolate.

\begin{tabular}{|c|c|c|c|}
\hline Antibiotic Resistance Genes & Location & Accession \# & Resistance Target \\
\hline$a a c\left(6^{\prime}\right)-I b-c r$ & Plasmid & DQ303918 & Aminoglycoside and fluoroquinolone resistance \\
\hline aad $A 5$ & Plasmid & AF137361 & Aminoglycoside resistance \\
\hline $\operatorname{aph}\left(3^{\prime \prime}\right)-I b$ & Plasmid & AF321551 & Aminoglycoside resistance \\
\hline $\operatorname{aph}(6)-I d$ & Plasmid & M28829 & Aminoglycoside resistance \\
\hline blaCTX-M-15 & Plasmid & AY044436 & Beta-lactam resistance \\
\hline blaOXA-1 & Plasmid & HQ170510 & Beta-lactam resistance \\
\hline blaKPC-2 & Plasmid & AY034847 & Beta-lactam resistance \\
\hline blaTEM-350 & Plasmid & WP045286946 & Beta-lactam resistance \\
\hline$m d f(A)$ & Chromosomal & Y08743 & Macrolide resistance \\
\hline$m p h(A)$ & Plasmid & D16251 & Macrolide resistance \\
\hline catB3 & Plasmid & AJ009818 & Phenicol resistance \\
\hline sul1 & Plasmid & U12338 & Sulphonamide resistance \\
\hline $\operatorname{tet}(A)$ & Plasmid & AJ517790 & Tetracycline resistance \\
\hline $\operatorname{tet}(B)$ & Chromosomal & AF32677 & Tetracycline resistance \\
\hline dfrA17 & Plasmid & FJ460238 & Trimethoprim resistance \\
\hline sit $A B C D$ & Plasmid & AY598030 & Disinfectant resistance \\
\hline$q a c E$ & Plasmid & X68232 & Disinfectant resistance \\
\hline bacA & Chromosomal & 3002986 & Peptide antibiotic resistance \\
\hline$m d t G$ & Chromosomal & 3001329 & MFS antibiotic efflux pump \\
\hline$m d t H$ & Chromosomal & 3001216 & MFS antibiotic efflux pump \\
\hline$m d t P$ & Chromosomal & 3003550 & MFS antibiotic efflux pump \\
\hline$m d t N$ & Chromosomal & 3003548 & MFS antibiotic efflux pump \\
\hline tolC & Chromosomal & 3000237 & MFS antibiotic efflux pump \\
\hline emrA & Chromosomal & 3000027 & MFS antibiotic efflux pump \\
\hline$e m r B$ & Chromosomal & 3000074 & MFS antibiotic efflux pump \\
\hline emrK & Chromosomal & 3000206 & MFS antibiotic efflux pump \\
\hline emrY & Chromosomal & 3000254 & MFS antibiotic efflux pump \\
\hline $\operatorname{evg} A$ & Chromosomal & 3000833 & MFS antibiotic efflux pump \\
\hline$H-N S$ & Chromosomal & 3000676 & MFS antibiotic efflux pump \\
\hline $\operatorname{ampH}$ & Chromosomal & 3004612 & ampC-type beta-lactamase \\
\hline $\operatorname{ampC1}$ & Chromosomal & 3004611 & ampC-type beta-lactamase \\
\hline $\operatorname{cpxA}$ & Chromosomal & 3000830 & RND Efflux pump \\
\hline $\operatorname{gadX}$ & Chromosomal & 3000508 & RND Efflux pump \\
\hline$m d t E$ & Chromosomal & 3000795 & RND Efflux pump \\
\hline$m d t F$ & Chromosomal & 3000796 & RND efflux pump \\
\hline $\operatorname{acr} A$ & Chromosomal & 3004043 & RND Efflux pump \\
\hline $\operatorname{acr} B$ & Chromosomal & 3000216 & RND Efflux pump \\
\hline $\operatorname{acrD}$ & Chromosomal & 3000491 & RND Efflux pump \\
\hline baes & Chromosomal & 3000829 & RND Efflux pump \\
\hline baeR & Chromosomal & 3000828 & RND Efflux pump \\
\hline $\operatorname{mar} A$ & Chromosomal & 3000263 & RND Efflux pump \\
\hline yojI & Chromosomal & 3003952 & Peptide antibiotic efflux pump \\
\hline pmrF & Chromosomal & 3003578 & Phosphoethanolamine transferase \\
\hline$k d p E$ & Chromosomal & 3003841 & Aminoglycoside efflux pump \\
\hline$m s b A$ & Chromosomal & 3003950 & Nitroimidazole efflux pump \\
\hline Point mutations & & PMID & \\
\hline parC AGC-> ATC & & 8851598 & Quinolone resistance \\
\hline parE TCG -> GCG & & 28598203 & Quinolone resistance \\
\hline gyrA TCG -> TTG & & 8891148 & Quinolone resistance \\
\hline gyrA GAC-> AAC & & 12654733 & Quinolone resistance \\
\hline
\end{tabular}

The following ARGs and mutations were identified by ResFinder 4.1 from the Center for Genomic Epidemiology and Comprehensive Antibiotic Resistance Database. MFS: major facilitator superfamily; RND: resistance nodulation-cell division.

The self-transmissible, multi-drug resistant plasmid pMHW-2 is rich in ARGs downstream of the type 1 integron integrase (Figure 3 and Supplementary Table S6: 14,76736,470 bps). pMHW-2 encoded two beta-lactamases, $b_{\text {CTX-M-15 }}$ and bla $a_{\text {OXA-1, with }}$ bla $a_{\mathrm{CTX}-\mathrm{M}-15}$ part of Tn2 between IS26 elements (Figure 3). Among clinical isolates, bla $a_{\mathrm{CTX}-\mathrm{M}-15}$ has been 
commonly identified on IncFI plasmids belonging to phylogroup A [63]. An IS26-composite transposon also contained bla OXA-1 along with type B-3 chloramphenicol O-acetyltransferase (catB3) and an aminoglycoside $6^{\prime}-\mathrm{N}$-acetyltransferase- $\mathrm{Ib}\left(a a c\left(6^{\prime}\right)-\mathrm{Ib}-\mathrm{cr}\right.$ ) gene (Figure 3 and Supplementary Table S6). This plasmid also contained a macrolide resistance gene $(m p h(A))$, tetracycline (tet $A)$, sulphonamide (sul1), trimethoprim (dfr17), and aminoglycoside (aadA5), as well as resistance genes to disinfectants (e.g., qacE and sit $A B C D$ ). The large presence of IS26 interspersed within plasmids and chromosomes of clinical and environmental isolates within the Enterobacteriaceae family supports a pivotal role in their dissemination of multi-drug resistance $[64,65]$. Beyond resistance, this plasmid encodes an iucABCD iutA operon responsible for the biosynthesis of the iron siderophore aerobactin. The production of aerobactin has been associated with increased virulence and relapse episodes of urinary tract infections $[66,67]$. Under iron-limiting and oxidative stress conditions, aerobactin has increased biofilm formation and hydrogen peroxide resistance respectively [68]. When the whole-genome sequence was analyzed with PathogenFinder [69], E. coli 1000C-3 matched 663 pathogenic families, resulting in a pathogen probability of 0.919 .

\subsection{Prevalence of Virulence Genes among CTX-Resistant Populations}

Antimicrobial resistant opportunistic pathogens pose an even bigger health risk. Another way to assess the potential pathogenic nature of a bacterial isolate is to identify encoded virulence factors, which are involved in an array of activities including attachment to host tissues, immune evasion, and production of toxins capable of tissue damage [70]. Frequently, these virulence factors are found on pathogenicity islands and other mobile genetic elements that allow for gene transfer [71]. We analyzed seven virulence genes comprising both cell surface and secreted virulence factors [70]. CTX-resistant clinical strains exhibited significantly more virulence genes compared to WW effluent isolates (Figure $4 \mathrm{~A}, p=0.0007$ ), where $64 \%$ of clinical isolates displayed three or more virulence genes compared to only $31 \%$ among WW effluent populations. Comparatively, the WW effluent isolates appeared to be less virulent; however, all encoded at least one virulence gene (Figure 4A).
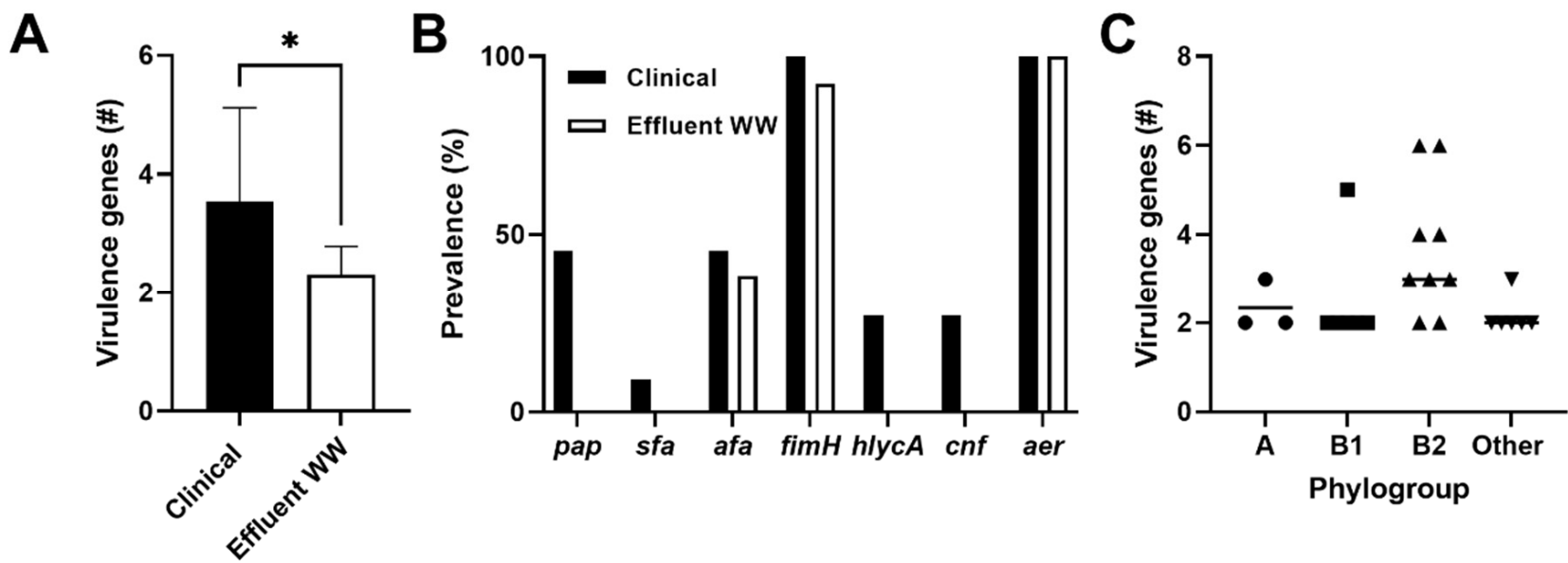

Figure 4. Virulence genes amongst CTX-resistant E. coli populations. (A) The mean number of virulence genes \pm standard deviation identified among clinical $E$. coli $(n=11$, black bars $)$ and treated WW effluent populations ( $n=16$, white bars). (B) Data represents the prevalence of each virulence factor among clinical isolates (black bars) and WW treated effluents (white bars). Percent prevalence was calculated by dividing total isolates positive for each virulence factor by the total isolates from the representative source. (C) Each point represents the number of virulence genes encoded by an E. coli isolate within the major phylogroups with the bar representing the mean number of virulence genes within the corresponding phylogroup. ${ }^{*} p=0.0007$. 
The virulence factor, aerobactin, was present in all clinical and effluent $E$. coli isolates. Aerobactin is frequently found among UPEC strains, is involved in iron sequestration, and is commonly associated with multi-drug resistance residing both on chromosomes and within plasmids [72]. Typically, aerobactin is associated with the presence of other virulence genes, such as type 1 fimbriae (fimH), hemolysin (hlyCA), and P fimbriae (papC) [73]. For our clinical strains, aerobactin and the adhesion gene, fim $\mathrm{H}$, were co-expressed; similar findings were evident among effluent strains where co-expression occurred among 93\% of the population (Figure 4B). Overall, virulence genes were significantly more abundant in the B2 phylogroup, regardless of source, compared to non-B2 phylogroups (Figure $4 \mathrm{C}, p<0.05$ ). This finding is consistent with other reports where phylogroup B2 has been associated with more virulence factors compared to other phylogroups [74,75]. In addition, we found that $75 \%$ of the B2 phylogroup isolates (from both clinical isolates and WW effluents) coexpressed aerobactin and afa adhesions (afa), a virulence factor commonly associated with UPEC [71]. However, due to the diversity and abundance of virulence genes in bacteria [76], it becomes difficult to attribute specific virulence genes to a pathogenic lineage, especially since they can be found among commensal strains [76]. Despite this limitation, our study detected similar virulence genes in both clinical samples and WW effluents including afa adhesions (Figure 4B) commonly associated with UPEC populations. These findings are consistent with a previous study identifying WW E. coli strains containing the same virulence factors as clinical UPEC isolates after whole-genome analysis [77]. Together, these findings implicate a potential pathogenic linkage emphasizing a health risk among treated effluent populations.

\section{Materials and Methods}

\subsection{Acquisition of CTX-Resistant E. coli Isolates}

WW samples were obtained from Jones Island Water Reclamation Facility (JI) and the Medical College of Wisconsin in Milwaukee, Wisconsin, USA. Facility employees acquired replicate 1L grab samples in sterile amber glass bottles (ThermoScientific, Waltham, MA, USA) once a week for three consecutive weeks in October 2018 from JI influent, treated effluent (post-primary and secondary treatment) and post-chlorinated disinfection effluents (final effluents entering environment). Hospital WW grab samples were acquired from two WW outflows at the Medical College of Wisconsin on two separate dates in October 2018. All samples were immediately placed on ice until it was processed within $8 \mathrm{~h}$. Various water volumes $(\leq 100 \mathrm{~mL})$ were filtered over a $0.45 \mu \mathrm{m}$ filter and placed on modified $\mathrm{mTEC}$ with cefotaxime $(4 \mu \mathrm{g} / \mathrm{mL})$ to obtain resistant $E$. coli populations. Random violet color colonies underwent further isolation by performing a four-quadrant streak on TSA with cefotaxime ( $2 \mu \mathrm{g} / \mathrm{mL})$ to ensure isolation. From these plates, $58 \mathrm{WW}$ isolates were obtained from hospital WW $(n=22)$, as well as influents $(n=19)$ and treated effluents $(n=17)$ with a maximum of 10 colony forming units (CFUs) per source per date. No CTX-resistant E. coli populations with the volumes tested were evident from one effluent sampling date and one hospital WW source on one date. Additionally, no CTX-resistant violet colonies were evident from post-chlorinated effluents in the volumes tested. Frozen glycerol stocks were made of all isolates for further analysis.

Clinical E. coli isolates (e.g., urinary tract (7), blood (2), wound (1), and surgical tissue (1)) from inpatient $(n=5)$ and outpatient $(n=6)$ samples were acquired from the same medical facility as the hospital WW. Presumptive E. coli colonies were confirmed using Bruker MALDI-TOF mass spectrometry [19]. Potential ESBL- and carbapenemaseproducing E. coli isolates were further identified using the BD Phoenix susceptibility system interfaced with the BD EpiCenter System V6.41 following Clinical \& Laboratory Standards Institute (CLSI) guidelines. Frozen glycerol stocks were made of all isolates for future analysis. 


\subsection{Antibiotic Susceptibility Testing}

The Kirby-Bauer disk diffusion method was used to determine the antibiotic resistance phenotypes of each isolate following CLSI guidelines [78]. Briefly, WW isolates were grown in tryptic soy broth overnight with cefotaxime $(2 \mu \mathrm{g} / \mathrm{mL})$. The susceptibility of all isolates was assessed after diluting overnight cultures to a MacFarland 0.5 standard followed by culturing them on Mueller Hinton plates stamped with the following antibiotics disks (BD BBL) - chloramphenicol (CHL, $30 \mathrm{mcg}$ ), sulfamethoxazole-trimethoprim (SXT, $23.75 / 1.25 \mathrm{mcg}$ ), ciprofloxacin (CIP, $5 \mathrm{mcg}$ ), gentamicin (GEN, $10 \mathrm{mcg}$ ), tetracycline (TET, $30 \mathrm{mcg})$, ceftriaxone (CRO, $30 \mathrm{mcg})$, ceftazidime (CAZ, $30 \mathrm{mcg})$, ceftazidime/clavulanic acid (CAZ/CLAV, 30/10 mcg), cefotaxime (CTX, $30 \mathrm{mcg}$ ), meropenem (MEM, $10 \mathrm{mcg}$ ), imipenem (IMP, $10 \mathrm{mcg}$ ), and ertapenem (ERT, $10 \mathrm{mcg}$ ). Zones of inhibition were measured after $18-24 \mathrm{~h}$ incubation at $35^{\circ} \mathrm{C}$ and susceptibility determined according to the $2020 \mathrm{CLSI}$ standards M100-S25 [79]. ESBL producers were identified among CTX-resistant populations if the zone of inhibition with the CAZ/CLAV acid disk was $\geq 5 \mathrm{~mm}$ compared to the CAZ alone zone of inhibition.

\subsection{Plasmid Isolation and Transformation}

Plasmids from CTX-resistant populations were isolated using a mini prep kit according to the manufacturer's instructions (Zymo Research, Irvine, CA, USA). Isolated plasmid DNA was then separated on a $0.7 \%$ agarose gel at $80 \mathrm{~V}$ for $3 \mathrm{~h}$. Gel images were captured after ethidium bromide staining for further analysis.

To identify resistant phenotypes associated with plasmids, they were transformed into Lucigen E. cloni ${ }^{\circledR} 10 \mathrm{G}$ chemically competent cells according to the manufacturer instructions (Lucigen, Middleton, WI, USA). Briefly, $4 \mu \mathrm{L}$ of plasmid DNA was added to $40 \mu \mathrm{l}$ of the competent cells and incubated on ice for $30 \mathrm{~min}$. Heat shock was performed for $90 \mathrm{~s}$ at $42{ }^{\circ} \mathrm{C}$ followed by ice for $2 \mathrm{~min}$. Recovery medium was added to the cells and incubated for $1 \mathrm{~h}$ at $37^{\circ} \mathrm{C}$ while shaking at $175 \mathrm{rpm}$. The reaction was plated on cefotaxime $(2 \mu \mathrm{g} / \mathrm{mL})$ plates and incubated overnight at $35^{\circ} \mathrm{C}$. Transformants were further tested for antibiotic susceptibility to determine antibiotic resistant phenotypes transmissible via plasmids.

\subsection{Identification of Beta-Lactamases and Virulence Genes}

A Promega Genomic DNA Purification kit was used to isolate genomic DNA of resistant strains. $\beta$-lactamase genes were further amplified using $2 X$ GoTaq Green PCR Master Mix (Promega Corp., Madison, WI, USA) and their associated primers (Supplementary Table S1). Isolated DNA from a Gram-negative carbapenemase detection panel (CDC \& FDA AR Isolate Bank, Atlanta, GA, USA) served as positive controls for ESBLs.

Detection of type 1 fimbriae (fimH), P fimbriae (papC), S and FIC fimbriae ( $s f a)$, Afa adhesin (afa), hemolysin (hlyCA), cytotoxic necrotizing factor (cnf), and aerobactin (aer) were all determined among clinical and treated effluent $E$. coli populations by PCR using primers listed in Supplementary Table S1 according to previous methods [70].

\subsection{Phylogroup Identification}

Phylotyping was performed according to the revised Clermont method [25]. Briefly, a quadruplex PCR was performed using primers (Supplementary Table S1) specific to the following genes: chuA, yjaA, TspE4.C2, and $\operatorname{arp} A$ to determine its associated phylogroup. Further characterization of some phylogroup $\mathrm{C}$ and $\mathrm{E}$ strains was performed using two additional allele-specific PCR primer pairs (Supplementary Table S1) to $\operatorname{arp} A$ and $\operatorname{trp} A$ as described by Clermont et al. All PCR products were visible after gel electrophoresis using a 1.0\% agarose gel with subsequent ethidium bromide staining.

\subsection{Whole Genome Sequencing and Analysis}

Genomic isolation was performed on E. coli 1000C-3 isolated from hospital WW that exhibited antibiotic resistance to third-generation cephalosporins and carbapenems. The 
Oxford Nanopore platform and NextSeq 2000 platform (Illumina, San Diego, CA, USA) were used to provide long and pair end reads $(2 \times 151 \mathrm{bp})$, respectively, for whole-genome sequencing. Illumina bcl2fastq 2.20.0.445 software and Porechop 0.2.3_seqan2.1.1 were performed on pair end reads and long reads, respectively, to perform quality control and adapter trimming. Unicycler 0.4 .8 was subsequently used to create a hybrid assembly between the two reads and provide closed genomes. The WGS is available at NCBI under BioProject ID SUB10978992 with accession numbers CP091427-CP091429.

The genome was submitted to JGI Integrated Microbial Genomes and Microbiomes (IMG/MER) for annotation and further analysis [80,81], including identifying putative horizontally transferred genes. Further analysis of assembled contigs were performed using the following web-based tools: PATRIC [82] for a comprehensive genome analysis; ResFinder 4.1 from the Center for Genomic Epidemiology [83] and Comprehensive Antibiotic Resistance Database (CARD) [84] to identify ARGs in the plasmid and chromosome; PlasmidFinder 2.1 and pMLST 2.0 to identify incompatibility types of plasmids [85]; MobileElementFinder v1.0.3 and IS Finder to identify mobile genetic elements [86,87]; SerotypeFinder 2.0 for serotyping [88]; oriTfinder 1.1 to identify oriT sites and MGEs [89]; and PathogenFinder 1.1 to determine the pathogenic potential [69]. Plasmid maps were comprised using the above tools and SnapGene software (from Insightful Science, San Diego, CA, USA; available at snapgene.com, accessed on 8 December 2021).

\subsection{Statistics}

Stata 12.1 software (College Station, TX, USA) and GraphPad Prism version 9.1.0 (GraphPad Software, San Diego, CA, USA) were used to perform all statistical tests. Fisher's exact test was used to determine differences in the prevalence of ARGs and virulence genes among E. coli from various water sources. One-way ANOVA with Tukey's post hoc test determined statistical differences between MAR indices. Correlations between antibiotic resistance phenotypes and genotypes were evaluated by Pearson's correlation test. Variation among total virulence factors used Welch's t-test.

\section{Conclusions}

With antibiotic resistance threatening global health, it is essential to understand the range and mechanisms of antibiotic resistance transmission [90] across diverse ecosystems. From this study, we can conclude the following: (1) hospital wastewater provides a rich source of multi-drug resistant $E$. coli populations and can serve as reservoirs of mobilizable ESBLs and carbapenemase entering sewer systems; (2) wastewater treatment and chlorine disinfection are critical mitigators in controlling AMR; (3) the prevalence and similarity of virulence factors among CTX-resistant $E$. coli in treated WW effluents are comparable to pathogenic strains in the same geographical area, further emphasizing the potential public health risk of treated wastewater into recreational waters. While this study demonstrates similarities in phenotypic and genotypic resistance across different ecosystems, additional sampling and more complete whole-genome sequencing would further support the evolutionary linkage between populations and enhance understanding the potential pathogenic nature of WW isolate populations.

Supplementary Materials: The following are available online at https://www.mdpi.com/article/ 10.3390/antibiotics11020260/s1, Table S1: Primers used in this study. Table S2: Antimicrobial susceptibility profiles present in E. coli isolates from different environments. Table S3: Phylogroups and sources of CTX-resistance. Table S4: Plasmid-mediated antibiotic resistant phenotypes. Table S5: PlasmidFinder incompatibility groupings of E. coli 1000C-3. Table S6: Annotation of E. coli 1000C-3 plasmids. Table S7: BLASTN results of nucleotide homology to E. coli 1000C-3 plasmids. References $[25,70,91-96]$ are cited in supplemantary materials.

Author Contributions: Conceptualization, K.R.H. and T.S.; methodology, E.L., B.B., R.E.B., C.C., K.R.H. and T.S.; validation, E.L. and T.S.; formal analysis, E.L., B.B. and T.S.; investigation, E.L., B.B., R.E.B., C.C., K.R.H. and T.S.; resources, K.R.H. and T.S.; data curation, E.L., B.B. and T.S.; writing- 
original draft preparation, E.L. and T.S.; writing-review and editing, E.L., B.B., R.E.B., C.C., K.R.H. and T.S.; visualization, E.L. and T.S.; supervision, K.R.H. and T.S.; project administration, K.R.H. and T.S.; funding acquisition, K.R.H. and T.S. All authors have read and agreed to the published version of the manuscript.

Funding: The data was funded by start-up funds (TS) from Department of Biomedical Sciences at the University of Wisconsin-Milwaukee and Explorer Challenge Grant (KH) from Marquette University.

Institutional Review Board Statement: Not applicable.

Informed Consent Statement: Not applicable.

Data Availability Statement: The genomic sequence of E. coli 1000C-3 is available at NCBI under BioProject ID SUB10978992 with accession numbers CP091427-CP091429.

Acknowledgments: We would like to thank Alyssa Severino, Sarah Duhr (UWM), and Bixia Su (Marquette University) for their laboratory assistance. The authors extend their acknowledgement to Kyle Leistikow (Marquette University) for assistance with the plasmid map.

Conflicts of Interest: The authors declare no conflict of interest.

\section{References}

1. CDC. Antibiotic Resistance Threats in the United States 2019; Department of Health and Human Services: Atlanta, GA, USA, 2019. [CrossRef]

2. McEwen, S.A.; Collignon, P.J. Antimicrobial Resistance: A One Health Perspective. Microbiol. Spectr. 2018, 6, 2. [CrossRef] [PubMed]

3. Al-Jassim, N.; Ansari, M.I.; Harb, M.; Hong, P.Y. Removal of bacterial contaminants and antibiotic resistance genes by conventional wastewater treatment processes in Saudi Arabia: Is the treated wastewater safe to reuse for agricultural irrigation? Water Res. 2015, 73, 277-290. [CrossRef] [PubMed]

4. Sharma, V.K.; Johnson, N.; Cizmas, L.; McDonald, T.J.; Kim, H. A review of the influence of treatment strategies on antibiotic resistant bacteria and antibiotic resistance genes. Chemosphere 2016, 150, 702-714. [CrossRef] [PubMed]

5. Aubertheau, E.; Stalder, T.; Mondamert, L.; Ploy, M.C.; Dagot, C.; Labanowski, J. Impact of wastewater treatment plant discharge on the contamination of river biofilms by pharmaceuticals and antibiotic resistance. Sci. Total Environ. 2017, 579, 1387-1398. [CrossRef]

6. Rizzo, L.; Manaia, C.; Merlin, C.; Schwartz, T.; Dagot, C.; Ploy, M.C.; Michael, I.; Fatta-Kassinos, D. Urban wastewater treatment plants as hotspots for antibiotic resistant bacteria and genes spread into the environment: A review. Sci. Total Environ. 2013, 447, 345-360. [CrossRef]

7. Korzeniewska, E.; Korzeniewska, A.; Harnisz, M. Antibiotic resistant Escherichia coli in hospital and municipal sewage and their emission to the environment. Ecotoxicol. Environ. Saf. 2013, 91, 96-102. [CrossRef]

8. Amador, P.P.; Fernandes, R.M.; Prudencio, M.C.; Barreto, M.P.; Duarte, I.M. Antibiotic resistance in wastewater: Occurrence and fate of Enterobacteriaceae producers of class A and class C beta-lactamases. J. Environ. Sci. Health 2015, 50, 26-39. [CrossRef]

9. Beattie, R.E.; Skwor, T.; Hristova, K.R. Survivor microbial populations in post-chlorinated wastewater are strongly associated with untreated hospital sewage and include ceftazidime and meropenem resistant populations. Sci. Total Environ. 2020, 740, 140186. [CrossRef]

10. Kappell, A.D.; DeNies, M.S.; Ahuja, N.H.; Ledeboer, N.A.; Newton, R.J.; Hristova, K.R. Detection of multi-drug resistant Escherichia coli in the urban waterways of Milwaukee, WI. Front. Microbiol. 2015, 6, 336. [CrossRef]

11. Centers for Disease Control and Prevention. Outpatient Antibiotic Prescriptions-United States, 2018; CDC: Atlanta, GA, USA, 2018.

12. Adegoke, A.A.; Madu, C.E.; Aiyegoro, O.A.; Stenstrom, T.A.; Okoh, A.I. Antibiogram and beta-lactamase genes among cefotaxime resistant E. coli from wastewater treatment plant. Antimicrob. Resist. Infect. Control. 2020, 9, 46. [CrossRef]

13. Paterson, D.L.; Bonomo, R.A. Extended-spectrum beta-lactamases: A clinical update. Clin. Microbiol. Rev. 2005, 18, 657-686. [CrossRef] [PubMed]

14. Silva, I.; Tacao, M.; Tavares, R.D.S.; Miranda, R.; Araujo, S.; Manaia, C.M.; Henriques, I. Fate of cefotaxime-resistant Enterobacteriaceae and ESBL-producers over a full-scale wastewater treatment process with UV disinfection. Sci. Total Environ. 2018, 639, 1028-1037. [CrossRef] [PubMed]

15. Hutinel, M.; Fick, J.; Larsson, D.G.J.; Flach, C.F. Investigating the effects of municipal and hospital wastewaters on horizontal gene transfer. Environ. Pollut. 2021, 276, 116733. [CrossRef] [PubMed]

16. Edberg, S.C.; Rice, E.W.; Karlin, R.J.; Allen, M.J. Escherichia coli: The best biological drinking water indicator for public health protection. Symp. Ser. Soc. Appl. Microbiol. 2000, 88, 106S-116S. [CrossRef] [PubMed]

17. Matic, I.; Rayssiguier, C.; Radman, M. Interspecies gene exchange in bacteria: The role of SOS and mismatch repair systems in evolution of species. Cell 1995, 80, 507-515. [CrossRef] 
18. Beattie, R.E.; Bakke, E.; Konopek, N.; Thill, R.; Munson, E.; Hristova, K.R. Antimicrobial Resistance Traits of Escherichia coli Isolated from Dairy Manure and Freshwater Ecosystems Are Similar to One Another but Differ from Associated Clinical Isolates. Microorganisms 2020, 8, 747. [CrossRef]

19. Bojar, B.; Sheridan, J.; Beattie, R.; Cahak, C.; Liedhegner, E.; Munoz-Price, L.S.; Hristova, K.R.; Skwor, T. Antibiotic resistance patterns of Escherichia coli isolates from the clinic through the wastewater pathway. Int. J. Hyg. Environ. Health 2021, $238,113863$. [CrossRef]

20. Nelson, R.E.; Hatfield, K.M.; Wolford, H.; Samore, M.H.; Scott, R.D., II; Reddy, S.C.; Olubajo, B.; Paul, P.; Jernigan, J.A.; Baggs, J. National Estimates of Healthcare Costs Associated With Multidrug-Resistant Bacterial Infections Among Hospitalized Patients in the United States. Clin. Infect. Dis. 2021, 72, S17-S26. [CrossRef]

21. Bezabih, Y.M.; Sabiiti, W.; Alamneh, E.; Bezabih, A.; Peterson, G.M.; Bezabhe, W.M.; Roujeinikova, A. The global prevalence and trend of human intestinal carriage of ESBL-producing Escherichia coli in the community. J. Antimicrob. Chemother. 2020, 76, 22-29. [CrossRef]

22. Marano, R.B.M.; Fernandes, T.; Manaia, C.M.; Nunes, O.; Morrison, D.; Berendonk, T.U.; Kreuzinger, N.; Tenson, T.; Corno, G.; Fatta-Kassinos, D.; et al. A global multinational survey of cefotaxime-resistant coliforms in urban wastewater treatment plants. Environ. Int. 2020, 144, 106035. [CrossRef]

23. Diwan, V.; Chandran, S.P.; Tamhankar, A.J.; Stalsby Lundborg, C.; Macaden, R. Identification of extended-spectrum beta-lactamase and quinolone resistance genes in Escherichia coli isolated from hospital wastewater from central India. J. Antimicrob. Chemother. 2012, 67, 857-859. [CrossRef] [PubMed]

24. Paulshus, E.; Kuhn, I.; Mollby, R.; Colque, P.; O'Sullivan, K.; Midtvedt, T.; Lingaas, E.; Holmstad, R.; Sorum, H. Diversity and antibiotic resistance among Escherichia coli populations in hospital and community wastewater compared to wastewater at the receiving urban treatment plant. Water Res. 2019, 161, 232-241. [CrossRef] [PubMed]

25. Clermont, O.; Christenson, J.K.; Denamur, E.; Gordon, D.M. The Clermont Escherichia coli phylo-typing method revisited: Improvement of specificity and detection of new phylo-groups. Environ. Microbiol. Rep. 2013, 5, 58-65. [CrossRef] [PubMed]

26. Schreiber, H.L.t.; Conover, M.S.; Chou, W.C.; Hibbing, M.E.; Manson, A.L.; Dodson, K.W.; Hannan, T.J.; Roberts, P.L.; Stapleton, A.E.; Hooton, T.M.; et al. Bacterial virulence phenotypes of Escherichia coli and host susceptibility determine risk for urinary tract infections. Sci. Transl. Med. 2017, 9, eaaf1283. [CrossRef]

27. Stoppe, N.C.; Silva, J.S.; Carlos, C.; Sato, M.I.Z.; Saraiva, A.M.; Ottoboni, L.M.M.; Torres, T.T. Worldwide Phylogenetic Group Patterns of Escherichia coli from Commensal Human and Wastewater Treatment Plant Isolates. Front. Microbiol. 2017, 8, 2512. [CrossRef]

28. Sabate, M.; Prats, G.; Moreno, E.; Balleste, E.; Blanch, A.R.; Andreu, A. Virulence and antimicrobial resistance profiles among Escherichia coli strains isolated from human and animal wastewater. Res. Microbiol. 2008, 159, 288-293. [CrossRef]

29. Rebello, R.C.; Regua-Mangia, A.H. Potential enterovirulence and antimicrobial resistance in Escherichia coli isolates from aquatic environments in Rio de Janeiro, Brazil. Sci. Total Environ. 2014, 490, 19-27. [CrossRef]

30. Gundogdu, A.; Jennison, A.V.; Smith, H.V.; Stratton, H.; Katouli, M. Extended-spectrum beta-lactamase producing Escherichia coli in hospital wastewaters and sewage treatment plants in Queensland, Australia. Can. J. Microbiol. 2013, 59, 737-745. [CrossRef]

31. Woerther, P.L.; Burdet, C.; Chachaty, E.; Andremont, A. Trends in Human Fecal Carriage of Extended-Spectrum beta-Lactamases in the Community: Toward the Globalization of CTX-M. Clin. Microbiol. Rev. 2013, 26, 744-758. [CrossRef]

32. Rhee, C.; Kadri, S.S.; Dekker, J.P.; Danner, R.L.; Chen, H.C.; Fram, D.; Zhang, F.; Wang, R.; Klompas, M.; Program, C.D.C.P.E. Prevalence of Antibiotic-Resistant Pathogens in Culture-Proven Sepsis and Outcomes Associated With Inadequate and BroadSpectrum Empiric Antibiotic Use. JAMA Netw. Open 2020, 3, e202899. [CrossRef]

33. Ruppe, E.; Lixandru, B.; Cojocaru, R.; Buke, C.; Paramythiotou, E.; Angebault, C.; Visseaux, C.; Djuikoue, I.; Erdem, E.; Burduniuc, O.; et al. Relative fecal abundance of extended-spectrum-beta-lactamase-producing Escherichia coli strains and their occurrence in urinary tract infections in women. Antimicrob. Agents Chemother. 2013, 57, 4512-4517. [CrossRef] [PubMed]

34. Dorado-Garcia, A.; Smid, J.H.; van Pelt, W.; Bonten, M.J.M.; Fluit, A.C.; van den Bunt, G.; Wagenaar, J.A.; Hordijk, J.; Dierikx, C.M.; Veldman, K.T.; et al. Molecular relatedness of ESBL/AmpC-producing Escherichia coli from humans, animals, food and the environment: A pooled analysis. J. Antimicrob. Chemother. 2018, 73, 339-347. [CrossRef]

35. Overdevest, I.; Willemsen, I.; Rijnsburger, M.; Eustace, A.; Xu, L.; Hawkey, P.; Heck, M.; Savelkoul, P.; Vandenbroucke-Grauls, C.; van der Zwaluw, K.; et al. Extended-Spectrum beta-Lactamase Genes of Escherichia coli in Chicken Meat and Humans, the Netherlands. Emerg. Infect. Dis. 2011, 17, 1216-1222. [CrossRef] [PubMed]

36. Canton, R.; Gonzalez-Alba, J.M.; Galan, J.C. CTX-M Enzymes: Origin and Diffusion. Front. Microbiol. 2012, 3, 110. [CrossRef] [PubMed]

37. Tanaka, H.; Hayashi, W.; Iimura, M.; Taniguchi, Y.; Soga, E.; Matsuo, N.; Kawamura, K.; Arakawa, Y.; Nagano, Y.; Nagano, N.; et al. Wastewater as a Probable Environmental Reservoir of Extended-Spectrum- $\beta$-Lactamase Genes: Detection of Chimeric $\beta$-Lactamases CTX-M-64 and CTX-M-123. Appl. Environ. Microbiol. 2019, 85, e01740-19. [CrossRef]

38. Castanheira, M.; Farrell, S.E.; Deshpande, L.M.; Mendes, R.E.; Jones, R.N. Prevalence of $\beta$-lactamase-encoding genes among Enterobacteriaceae bacteremia isolates collected in 26 U.S. hospitals: Report from the SENTRY Antimicrobial Surveillance Program (2010). Antimicrob. Agents Chemother. 2013, 57, 3012-3020. [CrossRef]

39. Denisuik, A.J.; Lagacé-Wiens, P.R.; Pitout, J.D.; Mulvey, M.R.; Simner, P.J.; Tailor, F.; Karlowsky, J.A.; Hoban, D.J.; Adam, H.J.; Zhanel, G.G. Molecular epidemiology of extended-spectrum $\beta$-lactamase-, AmpC $\beta$-lactamase- and carbapenemase-producing 
Escherichia coli and Klebsiella pneumoniae isolated from Canadian hospitals over a 5 year period: CANWARD 2007-11. J. Antimicrob. Chemother. 2013, 68 (Suppl. 1), i57-i65. [CrossRef]

40. Pai, H.; Choi, E.H.; Lee, H.J.; Hong, J.Y.; Jacoby, G.A. Identification of CTX-M-14 extended-spectrum beta-lactamase in clinical isolates of Shigella sonnei, Escherichia coli, and Klebsiella pneumoniae in Korea. J. Clin. Microbiol. 2001, 39, 3747-3749. [CrossRef]

41. Constantinides, B.; Chau, K.K.; Quan, T.P.; Rodger, G.; Andersson, M.I.; Jeffery, K.; Lipworth, S.; Gweon, H.S.; Peniket, A.; Pike, G.; et al. Genomic surveillance of Escherichia coli and Klebsiella spp. in hospital sink drains and patients. Microb. Genom. 2020, 6. [CrossRef]

42. Borgogna, T.R.; Borgogna, J.-L.; Mielke, J.A.; Brown, C.J.; Top, E.M.; Botts, R.T.; Cummings, D.E. High Diversity of CTX-M Extended-Spectrum $\beta$-Lactamases in Municipal Wastewater and Urban Wetlands. Microb. Drug Resist. 2016, 22, 312-320. [CrossRef]

43. Bevan, E.R.; Jones, A.M.; Hawkey, P.M. Global epidemiology of CTX-M $\beta$-lactamases: Temporal and geographical shifts in genotype. J. Antimicrob. Chemother. 2017, 72, 2145-2155. [CrossRef] [PubMed]

44. Branger, C.; Zamfir, O.; Geoffroy, S.; Laurans, G.; Arlet, G.; Thien, H.V.; Gouriou, S.; Picard, B.; Denamur, E. Genetic background of Escherichia coli and extended-spectrum beta-lactamase type. Emerg. Infect. Dis. 2005, 11, 54-61. [CrossRef]

45. Kutilova, I.; Medvecky, M.; Leekitcharoenphon, P.; Munk, P.; Masarikova, M.; Davidova-Gerzova, L.; Jamborova, I.; Bortolaia, V.; Pamp, S.J.; Dolejska, M. Extended-spectrum beta-lactamase-producing Escherichia coli and antimicrobial resistance in municipal and hospital wastewaters in Czech Republic: Culture-based and metagenomic approaches. Environ. Res. 2021, $193,110487$. [CrossRef] [PubMed]

46. Nzima, B.; Adegoke, A.A.; Ofon, U.A.; Al-Dahmoshi, H.O.M.; Saki, M.; Ndubuisi-Nnaji, U.U.; Inyang, C.U. Resistotyping and extended-spectrum beta-lactamase genes among Escherichia coli from wastewater treatment plants and recipient surface water for reuse in South Africa. New Microbes. New Infect. 2020, 38, 100803. [CrossRef] [PubMed]

47. Martínez, J.L.; Coque, T.M.; Baquero, F. What is a resistance gene? Ranking risk in resistomes. Nat. Rev. Microbiol. 2015, 13, 116-123. [CrossRef]

48. Wang, J.; Chu, L.; Wojnárovits, L.; Takács, E. Occurrence and fate of antibiotics, antibiotic resistant genes (ARGs) and antibiotic resistant bacteria (ARB) in municipal wastewater treatment plant: An overview. Sci. Total Environ. 2020, 744, 140997. [CrossRef]

49. Gillings, M.R.; Gaze, W.H.; Pruden, A.; Smalla, K.; Tiedje, J.M.; Zhu, Y.-G. Using the class 1 integron-integrase gene as a proxy for anthropogenic pollution. ISME J. 2015, 9, 1269-1279. [CrossRef]

50. Bonomo, R.A.; Burd, E.M.; Conly, J.; Limbago, B.M.; Poirel, L.; Segre, J.A.; Westblade, L.F. Carbapenemase-Producing Organisms: A Global Scourge. Clin. Infect. Dis. 2018, 66, 1290-1297. [CrossRef]

51. Logan, L.K.; Weinstein, R.A. The Epidemiology of Carbapenem-Resistant Enterobacteriaceae: The Impact and Evolution of a Global Menace. J. Infect. Dis. 2017, 215, S28-S36. [CrossRef]

52. Bettelheim, K.A. The sources of "OH" serotypes of Escherichia coli. J. Hyg. 1978, 80, 83-113. [CrossRef]

53. Dong, D.; Mi, Z.; Li, D.; Gao, M.; Jia, N.; Li, M.; Tong, Y.; Zhang, X.; Zhu, Y. Novel IncR/IncP6 Hybrid Plasmid pCRE3-KPC Recovered from a Clinical KPC-2-Producing Citrobacter braakii Isolate. mSphere 2020, 5, e00891-19. [CrossRef]

54. Stoesser, N.; Sheppard, A.E.; Peirano, G.; Anson, L.W.; Pankhurst, L.; Sebra, R.; Phan, H.T.T.; Kasarskis, A.; Mathers, A.J.; Peto, T.E.A.; et al. Genomic epidemiology of global Klebsiella pneumoniae carbapenemase (KPC)-producing Escherichia coli. Sci. Rep. 2017, 7, 5917. [CrossRef] [PubMed]

55. Garcia-Fernandez, A.; Villa, L.; Bibbolino, G.; Bressan, A.; Trancassini, M.; Pietropaolo, V.; Venditti, M.; Antonelli, G.; Carattoli, A. Novel Insights and Features of the NDM-5-Producing Escherichia coli Sequence Type 167 High-Risk Clone. mSphere 2020, 5, e00269-20. [CrossRef] [PubMed]

56. Alav, I.; Sutton, J.M.; Rahman, K.M. Role of bacterial efflux pumps in biofilm formation. J. Antimicrob. Chemother. 2018, 73, 2003-2020. [CrossRef] [PubMed]

57. Du, D.; Wang-Kan, X.; Neuberger, A.; van Veen, H.W.; Pos, K.M.; Piddock, L.J.V.; Luisi, B.F. Multidrug efflux pumps: Structure, function and regulation. Nat. Rev. Microbiol. 2018, 16, 523-539. [CrossRef] [PubMed]

58. Yao, Y.; Lazaro-Perona, F.; Falgenhauer, L.; Valverde, A.; Imirzalioglu, C.; Dominguez, L.; Cantón, R.; Mingorance, J.; Chakraborty, T. Insights into a Novel bla(KPC-2)-Encoding IncP-6 Plasmid Reveal Carbapenem-Resistance Circulation in Several Enterobacteriaceae Species from Wastewater and a Hospital Source in Spain. Front. Microbiol. 2017, 8, 1143. [CrossRef] [PubMed]

59. Yeo, C.C.; Tham, J.M.; Kwong, S.M.; Yiin, S.; Poh, C.L. Tn5563, a transposon encoding putative mercuric ion transport proteins located on plasmid pRA2 of Pseudomonas alcaligenes. FEMS Microbiol. Lett. 1998, 165, 253-260. [CrossRef]

60. Rozwandowicz, M.; Brouwer, M.S.M.; Fischer, J.; Wagenaar, J.A.; Gonzalez-Zorn, B.; Guerra, B.; Mevius, D.J.; Hordijk, J. Plasmids carrying antimicrobial resistance genes in Enterobacteriaceae. J. Antimicrob. Chemother. 2018, 73, 1121-1137. [CrossRef]

61. Koraimann, G. Spread and Persistence of Virulence and Antibiotic Resistance Genes: A Ride on the F Plasmid Conjugation Module. EcoSal Plus 2018, 8. [CrossRef]

62. Rinkel, M.; Hubert, J.C.; Roux, B.; Lett, M.C. Identification of a new transposon Tn5403 in a Klebsiella pneumoniae strain isolated from a polluted aquatic environment. Curr. Microbiol. 1994, 29, 249-254. [CrossRef]

63. Mshana, S.E.; Imirzalioglu, C.; Hossain, H.; Hain, T.; Domann, E.; Chakraborty, T. Conjugative IncFI plasmids carrying CTX-M-15 among Escherichia coli ESBL producing isolates at a University hospital in Germany. BMC Infect. Dis. 2009, 9, 97. [CrossRef] [PubMed] 
64. Harmer, C.J.; Moran, R.A.; Hall, R.M. Movement of IS26-associated antibiotic resistance genes occurs via a translocatable unit that includes a single IS26 and preferentially inserts adjacent to another IS26. mBio 2014, 5, e01801-e01814. [CrossRef] [PubMed]

65. Varani, A.; He, S.; Siguier, P.; Ross, K.; Chandler, M. The IS6 family, a clinically important group of insertion sequences including IS26. Mob. DNA-Uk 2021, 12, 11. [CrossRef]

66. Russo, T.A.; Olson, R.; MacDonald, U.; Metzger, D.; Maltese, L.M.; Drake, E.J.; Gulick, A.M.; Camilli, A. Aerobactin Mediates Virulence and Accounts for Increased Siderophore Production under Iron-Limiting Conditions by Hypervirulent (Hypermucoviscous) Klebsiella pneumoniae. Infect. Immun. 2014, 82, 2356-2367. [CrossRef]

67. Soto, S.M.; Smithson, A.; Horcajada, J.P.; Martinez, J.A.; Mensa, J.P.; Vila, J. Implication of biofilm formation in the persistence of urinary tract infection caused by uropathogenic Escherichia coli. Clin. Microbiol. Infect. 2006, 12, 1034-1036. [CrossRef]

68. Li, C.; Pan, D.; Li, M.; Wang, Y.; Song, L.; Yu, D.; Zuo, Y.; Wang, K.; Liu, Y.; Wei, Z.; et al. Aerobactin-Mediated Iron Acquisition Enhances Biofilm Formation, Oxidative Stress Resistance, and Virulence of Yersinia pseudotuberculosis. Front. Microbiol. 2021, 12 [CrossRef]

69. Cosentino, S.; Voldby Larsen, M.; Møller Aarestrup, F.; Lund, O. PathogenFinder-Distinguishing Friend from Foe Using Bacterial Whole Genome Sequence Data. PLoS ONE 2013, 8, e77302. [CrossRef]

70. Tarchouna, M.; Ferjani, A.; Ben-Selma, W.; Boukadida, J. Distribution of uropathogenic virulence genes in Escherichia coli isolated from patients with urinary tract infection. Int. J. Infect. Dis. 2013, 17, e450-e453. [CrossRef]

71. Sarowska, J.; Futoma-Koloch, B.; Jama-Kmiecik, A.; Frej-Madrzak, M.; Ksiazczyk, M.; Bugla-PLoSkonska, G.; Choroszy-Krol, I. Virulence factors, prevalence and potential transmission of extraintestinal pathogenic Escherichia coli isolated from different sources: Recent reports. Gut. Pathog. 2019, 11, 10. [CrossRef]

72. Johnson, J.R.; Kuskowski, M.A.; Gajewski, A.; Sahm, D.F.; Karlowsky, J.A. Virulence characteristics and phylogenetic background of multidrug-resistant and antimicrobial-susceptible clinical isolates of Escherichia coli from across the United States, $2000-2001$. J. Infect. Dis. 2004, 190, 1739-1744. [CrossRef]

73. Johnson, J.R.; Moseley, S.L.; Roberts, P.L.; Stamm, W.E. Aerobactin and other virulence factor genes among strains of Escherichia coli causing urosepsis: Association with patient characteristics. Infect. Immun. 1988, 56, 405-412. [CrossRef] [PubMed]

74. Calhau, V.; Mendes, C.; Pena, A.; Mendonca, N.; Da Silva, G.J. Virulence and plasmidic resistance determinants of Escherichia coli isolated from municipal and hospital wastewater treatment plants. J. Water Health 2015, 13, 311-318. [CrossRef]

75. Picard, B.; Garcia, J.S.; Gouriou, S.; Duriez, P.; Brahimi, N.; Bingen, E.; Elion, J.; Denamur, E. The link between phylogeny and virulence in Escherichia coli extraintestinal infection. Infect. Immun. 1999, 67, 546-553. [CrossRef] [PubMed]

76. Qin, X.; Hu, F.; Wu, S.; Ye, X.; Zhu, D.; Zhang, Y.; Wang, M. Comparison of adhesin genes and antimicrobial susceptibilities between uropathogenic and intestinal commensal Escherichia coli strains. PLoS ONE 2013, 8, e61169. [CrossRef] [PubMed]

77. Zhi, S.; Stothard, P.; Banting, G.; Scott, C.; Huntley, K.; Ryu, K.; Otto, S.; Ashbolt, N.; Checkley, S.; Dong, T.; et al. Characterization of water treatment-resistant and multidrug-resistant urinary pathogenic Escherichia coli in treated wastewater. Water Res. 2020, 182, 115827. [CrossRef] [PubMed]

78. CLSI. Methods for Dilution Antimicrobial Susceptibility Tests for Bacteria that Grow Aerobically, Approved Standard, CLSI Document M07-A10, 10th ed.; Clinical and Laboratory Standards Institute: Wayne, PA, USA, 2015.

79. CLSI. Performance Standards for Antimicrobial Susceptibility Testing, Twenty-Fifth Informational Supplement, CLSI Document M100-S25; Clinical and Laboratory Standards Insititute: Wayne, PA, USA, 2015.

80. Chen, I.M.A.; Chu, K.; Palaniappan, K.; Ratner, A.; Huang, J.; Huntemann, M.; Hajek, P.; Ritter, S.; Varghese, N.; Seshadri, R.; et al. The IMG/M data management and analysis system v.6.0: New tools and advanced capabilities. Nucleic Acids Res. 2021, 49, D751-D763. [CrossRef]

81. Mukherjee, S.; Stamatis, D.; Bertsch, J.; Ovchinnikova, G.; Sundaramurthi, J.C.; Lee, J.; Kandimalla, M.; Chen, I.M.A.; Kyrpides, N.C.; Reddy, T.B.K. Genomes OnLine Database (GOLD) v.8: Overview and updates. Nucleic Acids Res. 2021, 49, D723-D733. [CrossRef]

82. Wattam, A.R.; Davis, J.J.; Assaf, R.; Boisvert, S.; Brettin, T.; Bun, C.; Conrad, N.; Dietrich, E.M.; Disz, T.; Gabbard, J.L.; et al. Improvements to PATRIC, the all-bacterial Bioinformatics Database and Analysis Resource Center. Nucleic Acids Res. 2017, 45, D535-D542. [CrossRef]

83. Bortolaia, V.; Kaas, R.S.; Ruppe, E.; Roberts, M.C.; Schwarz, S.; Cattoir, V.; Philippon, A.; Allesoe, R.L.; Rebelo, A.R.; Florensa, A.F.; et al. ResFinder 4.0 for predictions of phenotypes from genotypes. J. Antimicrob. Chemother. 2020, 75, 3491-3500. [CrossRef]

84. McArthur, A.G.; Waglechner, N.; Nizam, F.; Yan, A.; Azad, M.A.; Baylay, A.J.; Bhullar, K.; Canova, M.J.; De Pascale, G.; Ejim, L.; et al. The comprehensive antibiotic resistance database. Antimicrob. Agents Chemother. 2013, 57, 3348-3357. [CrossRef]

85. Carattoli, A.; Zankari, E.; García-Fernández, A.; Voldby Larsen, M.; Lund, O.; Villa, L.; Møller Aarestrup, F.; Hasman, H. In silico detection and typing of plasmids using PlasmidFinder and plasmid multilocus sequence typing. Antimicrob. Agents Chemother. 2014, 58, 3895-3903. [CrossRef] [PubMed]

86. Siguier, P.; Perochon, J.; Lestrade, L.; Mahillon, J.; Chandler, M. ISfinder: The reference centre for bacterial insertion sequences. Nucleic Acids Res. 2006, 34, D32-D36. [CrossRef] [PubMed]

87. Johansson, M.H.K.; Bortolaia, V.; Tansirichaiya, S.; Aarestrup, F.M.; Roberts, A.P.; Petersen, T.N. Detection of mobile genetic elements associated with antibiotic resistance in Salmonella enterica using a newly developed web tool: MobileElementFinder. J. Antimicrob. Chemother. 2021, 76, 101-109. [CrossRef] [PubMed] 
88. Joensen, K.G.; Tetzschner, A.M.M.; Iguchi, A.; Aarestrup, F.M.; Scheutz, F. Rapid and Easy In Silico Serotyping of Escherichia coli Isolates by Use of Whole-Genome Sequencing Data. J. Clin. Microbiol. 2015, 53, 2410-2426. [CrossRef]

89. Li, X.; Xie, Y.; Liu, M.; Tai, C.; Sun, J.; Deng, Z.; Ou, H.-Y. oriTfinder: A web-based tool for the identification of origin of transfers in DNA sequences of bacterial mobile genetic elements. Nucleic Acids Res. 2018, 46, W229-W234. [CrossRef]

90. WHO. Global Action Plan on Antimicrobial Resistance; WHO: Geneva, Switzerland, 2015.

91. Eckert, C.; Gautier, V.; Arlet, G. DNA sequence analysis of the genetic environment of various blaCTX-M genes. J. Antimicrob. Chemother. 2006, 57, 14-23. [CrossRef]

92. Yagi, T.; Kurokawa, H.; Shibata, N.; Shibayama, K.; Arakawa, Y. A preliminary survey of extended-spectrum $\beta$-lactamases (ESBLs) in clinical isolates of Klebsiella pneumoniae and Escherichia coli in Japan. FEMS Microbiol. Lett. 2000, 184, 53-56. [CrossRef]

93. McNeece, G.; Naughton, V.; Woodward, M.J.; Dooley, J.S.; Naughton, P.J. Array based detection of antibiotic resistance genes in Gram negative bacteria isolated from retail poultry meat in the UK and Ireland. Int. J. Food Microbiol. 2014, 179, 24-32. [CrossRef]

94. Dallenne, C.; Da Costa, A.; Decre, D.; Favier, C.; Arlet, G. Development of a set of multiplex PCR assays for the detection of genes encoding important beta-lactamases in Enterobacteriaceae. J. Antimicrob. Chemother. 2010, 65, 490-495. [CrossRef]

95. Colom, K.; Perez, J.; Alonso, R.; Fernandez-Aranguiz, A.; Larino, E.; Cisterna, R. Simple and reliable multiplex PCR assay for detection of blaTEM, bla(SHV) and blaOXA-1 genes in Enterobacteriaceae. FEMS Microbiol. Lett. 2003, 223, 147-151. [CrossRef]

96. Levesque, C.; Piche, L.; Larose, C.; Roy, P.H. PCR mapping of integrons reveals several novel combinations of resistance genes. Antimicrob. Agents Chemother. 1995, 39, 185-191. [CrossRef] [PubMed] 